\title{
С.П. САВЧУК
}

Сергій Петрович Савчук, аспірант Інституту держави і права імені В.М. Корецького НАН України* ORCID: 0000-0002-3162-2369

\section{ОСОБЛИВОСТІ ПРАВОВОГО РЕГУЛЮВАННЯ СТРОКОВИХ ТРУДОВИХ ДОГОВОРІВ В ОКРЕМИХ ЄВРОПЕЙСЬКИХ КРАЇНАХ}

Постановка проблеми. Строкові трудові договори слід віднести до однієї з найперших та, відповідно, найстаріших форм нестандартної зайнятості. Це зумовлено передусім природною неоднорідністю трудових правовідносин, для яких не завжди характерним є безстроковий характер. Зазначена обставина була врахована ще першими вітчизняними кодифікованими актами у сфері праці. Наприклад, ст. 34 Кодексу законів про працю 1922 р. закріплювала можливість укладання трудових договорів на певний строк, не більше одного року, або на час виконання певної роботи. У сучасних умовах правове регулювання строкових трудових договорів знаходить своє відображення у ст. 23 Кодексу законів про працю України. Але у зв'язку з тим, що останні зміни у наведену статтю були внесені ще 25 років тому, відповідність ії положень сучасним вимогам викликає великий сумнів. У свою чергу, якщо казати про концепцію застосування строкових трудових договорів в Україні у найближчий перспективі, то можливість ії̈ подальшого розвитку вбачається доречним розглядати крізь призму європейського досвіду. Адже в багатьох країнах Європи строкові трудові договори $\epsilon$ досить поширеним явищем, а тому дослідження як позитивних, так і негативних прикладів правового регулювання таких договорів у наведених країнах стане в пригоді при подальшому розробленні та запровадженні сучасних трудоправових норм в Україні.

Аналіз останніх досліджень і публікацій. Дослідженню окремих питань правового регулювання строкових трудових договорів в зарубіжних країнах присвячені роботи С.В. Венедіктова, М.М. Грекової, І.Я. Кисельова, О.І. Кисельової, М.М. Клемпарського, О.В. Назимко, Г.О. Спіциної, Ю.В. Чижмаря, P.I. Шабанова та інших вчених. Незважаючи на наявні наукові дослідження, питання правового регулювання трудових договорів не втрачають своєї актуальності з огляду на постійну динаміку розвитку наведеного явища в світі.

Формулювання мети статті. Метою даної статті $\epsilon$ аналіз правового регулювання строкових трудових договорів в окремих економічно та соціально розвинених європейських країнах, що в подальшому дасть змогу розробити більш ефективну модель реформування трудового законодавства України.

Виклад основного матеріалу. Звертаючись до дослідження особливостей правового регулювання строкових трудових договорів в країнах Європи, хотілось би підкреслити, що значну частину наведених країн об'єднає спільне членство в Свропейському Союзі (далі - СС) і, відповідно, необхідність імплементації в національне законодавство актів цього економічного та політичного об'єднання. Одним із таких актів ЄС слід назвати Директиву Ради 1999/70/ЄС від 28 червня 1999 р. про Рамкову угоду про роботу на визначений термін, укладену ЄКПС, СКПРЄ та ЄЦРП. Метою цієї Рамкової угоди є поліпшення якості строкової праці шляхом забезпечення застосування принципу недискримінації, а також створення основи для запобігання зловживанням, що виникають у результаті використання послідовних строкових трудових договорів або відносин. Відповідно до п. 4 цієї Рамкової угоди до працівників, що працюють за строковими договорами, не можна ставитися менш сприятливо, ніж до постійних працівників тільки тому, що з ними укладені строкові договори. Згідно з п. 5 цієї Рамкової угоди для запобігання зловживанням, що виникають в результаті використання послідовних строкових трудових договорів або правовідносин, держави мають встановити об’єктивні причини, що виправдовують відновлення таких договорів або правовідносин, їх максимальну загальну тривалість та кількість продовжень.

Незважаючи на наявність наведеного об'єднуючого фактору, кожна країна - член ЄС, відрізняється своєю самобутністю та специфікою національного трудового права, що не може не позначитись на регулюванні строкових трудових договорів. У свою чергу, у зв'язку з тим, що обсяги дослідження не дають змоги охопити спеціальне трудове законодавство усіх європейських країн, автором у подальшому буде зосереджена увага на таких географічно розпорошених державах, як Великобританія, Естонія, Італія, Польща та Франція.

Слід зазначити, що Великобританія є єдиною з країн, охоплених цим дослідженням, яка не є членом ЄС. Але іiі досить тривале перебування у складі зазначеного економічного та політичного об'єднання не могло не позначитися на національному трудовому законодавстві, в тому числі присвяченому строковим трудовим договорам. Так, регулювання наведених договорів у державі здійснюється на рівні Положення про працівників, працюючих за строковими трудовими договорами 2002 р. Якщо звернутися до змісту зазначеного Положення, то можна побачити, що воно продиктоване вимогами саме Директиви Ради 1999/70/СС та розроблене для запровадження принципу недискримінації строкових та тимчасових працівників. Положення

(C) С.П. Савчук, 2020

* Sergiy Savchuk, Postgraduate student of V.M. Koretsky Institute of State and Law of NAS of Ukraine 
поширюється на осіб, з якими укладено трудовий договір для заміни тимчасово відсутніх працівників (у зв'язку з відпусткою по вагітності та пологах, батьківською відпусткою тощо), осіб, найнятих на період максимального попиту на послуги роботодавця, виконавців спеціальних завдань (наприклад, налаштування бази даних), викладачів закладів вищої освіти, керівного складу сфери охорони здоров'я та інших ${ }^{1}$. Пункт 3 наведеного Положення передбачає право працівника, працюючого за строковим трудовим договором, на не менш сприятливе ставлення до себе з боку роботодавця порівняно 3 постійним працівником в частині умов трудового договору та можливості проходження професійного навчання або отримання постійної посади.

Як правило, строкові трудові договори у Великобританії укладаються у випадках, коли роботодавцям заздалегідь відомо про необхідність отримання певних послуг від працівників. Щодо такого трудового договору дата його припинення визначається заздалегідь. У деяких ситуаціях строковий договір може передбачати, що робота припиняється після виконання відповідного завдання або настання певної події, наприклад, закінчення будівництва. Юридичне визначення поняття звільнення у такому випадку відповідає припиненню таких «обмежених в часі» договорів для цілей подання скарги про несправедливе звільнення або отримання компенсації при скороченні штату².

Звільнення, яке має місце в цьому випадку, повинно бути перевіреним на законність в частині обгрунтованості дій роботодавця щодо невідновлення договору. Існування реальної потреби в укладенні 3 працівником строкового трудового договору (наприклад, у зв'язку зі строковим характером праці або досягненням конкретної мети) вважається обгрунтованою підставою для непереукладення договору після його закінчення. Але важливо, щоб працівники не позбавлялись їх законних прав шляхом маскування звичайних трудових правовідносин строковими трудовими договорами. У випадку, коли в подальшому строковий трудовий договір припиниться, дії роботодавця вважатимуться необгрунтованими, якщо він фактично відмовиться розглядати працівника для іншої підходящої роботи ${ }^{3}$. Право на обгрунтованість звільнення та отримання компенсації у випадку скорочення виникає у працівника після двох років роботи у конкретного роботодавця. При цьому слід зазначити, що починаючи з 1999 р. роботодавців позбавили можливості вимагати від працівників відмови від їх гарантій при несправедливому звільненні у випадку припинення строкового трудового договору, а починаючи з 2002 р. була ліквідована можливість працівників відмовлятися від вимоги про компенсацію у випадку звільнення у зв'язку зі скороченням штату4.

Положеннями строкового трудового договору може бути передбачена можливість його дострокового розірвання. У цьому випадку мінімальний термін повідомлення роботодавцем працівника про дострокове розірвання становить: один тиждень, якщо працівник працював безперервно в роботодавця не менше одного місяця; один тиждень за кожен рік роботи, якщо він працює безперервно протягом двох років або більше. Працівники, які бажають звільнитися, повинні повідомити роботодавця за один тиждень, якщо вони пропрацювали у нього місяць або більше. Якщо працівник продовжує працювати після закінчення строкового трудового договору, вважається, що дата припинення правовідносин змінилася. Тобто роботодавець зобов'язаний у подальшому надати працівникові повідомлення про розірвання договору5. Зазначене правило не застосовується у випадку, якщо працівник працює на роботодавця більше чотирьох років. У цьому разі договір вважається таким, що укладений на невизначений термін, якщо положеннями колективного договору не передбачене інше.

Цікавим прикладом реалізації строкових трудових договорів слід назвати Естонію, яку поєднує з Україною спільне соціалістичне минуле i, відповідно, правове підгрунтя регулювання трудових відносин. Ключовий нормативний акт у сфері праці Естонії - Закон про трудовий договір передбачає, що за загальним правилом трудовий договір укладається на невизначений строк, строковий договір може бути укладений на термін до п’яти років, якщо це виправдано поважними причинами, що випливають 3 тимчасового термінового характеру роботи. Якщо трудові обов'язки виконуються в порядку оренди праці, то строковий договір можна укласти і в разі, якщо це виправдано тимчасовим характером роботи на підприємстві користувача. Строковий трудовий договір також може бути укладеним на час заміщення тимчасово відсутнього працівника.

Якщо працівник і роботодавець уклали строковий трудовий договір для виконання однотипної роботи більше двох разів поспіль, або якщо строковий договір був продовжений більш ніж один раз протягом п’яти років, то трудові відносини вважаються безстроковими з самого початку. Укладення строкових трудових договорів вважається послідовним, якщо період між завершенням одного трудового договору та укладенням наступного трудового договору не перевищує двох місяців.

В Естонії закон зобов'язує роботодавця повідомити працівника, що працює за строковим трудовим договором, про вакантні робочі місця, які відповідають його знанням та навичкам, для заміщення яких $є$ можливість укладати безстроковий трудовий договір. Строковий трудовий договір припиняється після закінчення терміну, на який він був укладений. Але він може бути також розірваний у будь-який час за взаємною згодою сторін. Якщо укладення строкового трудового договору суперечило закону або колективному договору, то договір вважається безстроковим з моменту його укладення. У випадку, коли працівник продовжує виконання роботи після закінчення терміну договору, він вважається безстроковим, за винятком, коли роботодавець висловив іншу волю протягом п’яти робочих днів з того моменту, коли він дізнався або повинен був дізнатися про те, що працівник продовжує виконання трудового договору.

Правове регулювання строкових трудових договорів в Imaлії здійснюється на рівні Декрету № 81/2015 від 15 червня 2020 р., який у 2018 р. зазнав суттєвих змін. Хоча трудові правовідносини знаходять свою загальну реалізацію у формі безстрокового трудового договору, строкові договори можуть бути більш гнучким інструментом, що за певних обставин відповідає потребам як роботодавця, так і працівника. 3 цієї причини використання строкового трудового договору зазнає певних обмежень. Так, наведений договір укладається в письмовій формі, за винятком тих випадків, коли він триває не більше 20 днів. Працівник, що упро- 
довж шести місяців працює за строковим трудовим договором, має переважне право протягом одного року після звільнення на укладення нового трудового договору для виконання тих самих завдань. Загальна кількість укладених у одного роботодавця строкових трудових договорів не може перевищувати 30 \% від загальної кількості трудових договорів 6 .

Як вже зазначалося, у 2018 р. правове регулювання строкових трудових договорів в Італії зазнало суттєвих змін. Так, максимальна тривалість договору, включаючи продовження та переукладення, була зменшена 3 36 до 24 місяців. Якщо строковий трудовий договір має початкову тривалість не більше 12 місяців, роботодавець може не вказувати жодної поважної причини для його укладення. У випадку, коли строк договору перевищує 12 місяців, його укладення повинно буди виправданим принаймні однією 3 наступних поважних причин: необхідністю замінити відсутнього працівника; тимчасовими об'єктивними потребами, які не пов'язані зі звичайним ходом бізнесу; непередбачуваним збільшенням виробництва. Недотримання однієї з цих поважних причин тягне за собою юридичне перетворення строкового трудового договору у безстроковий7.

Ключовим актом, присвяченим регулюванню строкових трудових договорів у Польщі, є Трудовий кодекс, прийнятий ще у 1974 р. 3 цього приводу слід повністю погодитись 3 Г.О. Спіциною, яка зазначає, що завдяки вдалому переформуванню вектору правового регулювання трудових відносин у Польщі законодавчим органам вказаної держави вдалося пристосувати положення соціалістично сформованого трудового кодексу до реалій розвиненої ринкової економіки та членства в Свропейському Союзі. Тому запозичення такого досвіду модернізації трудового законодавства було б дуже корисним для України 8 .

Відповідно до ст. 25 Трудового кодексу Польщі термін працевлаштування за строковим трудовим договором, а також загальний термін працевлаштування за декількома строковими трудовими договорами, укладеними між одними і тими ж сторонами трудових правовідносин, не може перевищувати 33 місяці, а загальна кількість цих договорів не може перевищувати трьох. Якщо період найму за строковим трудовим договором $є$ більшим за зазначений термін або якщо кількість укладених договорів перевищує три договори, вважається, що працівник працює за безстроковим трудовим договором.

Як ми бачимо, зазначена норма повною мірою відповідає положенням Директиви Ради 1999/70/СС. Цікавим прикладом впливу наведеної Директиви на трудове законодавство Польщі слід навести рішення Суду СС по справі C 38/13 (Nierodzik), ухвалене у 2014 р. Зазначеним рішенням було встановлено, що відповідно до діючої на той час редакції ст. 33 Трудового кодексу Польщі при укладенні трудового договору на строк більше шести місяців сторони можуть передбачити, що зазначений договір може бути розірваний достроково після двотижневого повідомлення. У свою чергу, згідно зі ст. 36 Кодексу, максимальний термін повідомлення про припинення безстрокового трудового договору становить три місяці. Судом було визначено, що такі різні правила щодо працівників, які працюють за строковими та безстроковими трудовими договорами, не можуть бути об'єктивно обгрунтованими та порушують принцип недискримінації, передбачений Директивою Ради 1999/70/СС. Враховуючи наведене рішення Суду СС, у 2016 р. в Трудовий кодекс Польщі були внесені зміни, відповідно до яких період повідомлення для строкових трудових договорів приведено у відповідність з періодом повідомлення для безстрокових трудових договорів, що залежить від сукупної тривалості трудових правовідносин з конкретним роботодавцем. Таким чином, на цей час строковий трудовий договір може бути розірваний з наступним повідомленням: два тижні - якщо працівник працював менше шести місяців; один місяць - якщо працівник працював не менше шести місяців; три місяці - якщо працівник працював не менше трьох років.

Правове регламентування трудових відносин у Францї̈, на думку Г.В. Шонії, характеризується значною диференціацією, яка враховує різноманіття та специфіку праці різних категорій працівників, форм зайнятості. У зв’язку з цим існує велика кількість різновидів трудового договору, серед яких можна виділити: договір із позиковими працівниками та договір із певним терміном дії. Французьке законодавство стимулює використання строкових трудових договорів як засіб боротьби з безробіттям. Крім того, окремо регламентується трудовий договір з торговими агентами, з професійними спортсменами, з надомниками, 3 домашніми працівниками, договір морського найму, виробничого навчання та деякі інші 9 .

Слід зазначити, що серед усіх країн, охоплених цим дослідженням, лише тільки Франція ратифікувала Конвенцію 1982 року про припинення трудових правовідносин з ініціативи роботодавця (№ 158). Зазначену Конвенцію доповнює Рекомендація № 166, ст. 3 якої вказує на необхідність встановлення відповідних гарантій проти застосування договорів про найняття на певний термін. Серед таких гарантій положення Рекомендації виділяють обмеження застосування строкових трудових договорів випадками, коли, враховуючи рід майбутньої роботи або умови ії виконання чи інтереси працівника, ці трудові відносини не можуть встановлюватися на невизначений термін. У зв’язку з цим Трудовий кодекс Франції закріплює чіткі критерії, що передбачають можливість укладання строкових трудових договорів.

Трудові договори укладаються на відповідний строк у випадках: а) заміни тимчасово відсутнього працівника (у зв'язку з хворобою, вагітністю й пологами, щорічною відпусткою, батьківською відпусткою, навчанням etc.); б) професійного навчання працівника; в) нетривалого збільшення господарської активності роботодавця (e.g. під час новорічних і різдвяних свят); г) сезонного найму на роботу; д) перепрофілювання господарської діяльності роботодавця; е) забезпечення тимчасової зайнятості безробітних еtc. Строкові трудові договори не можуть мати місця, якщо діяльність майбутнього працівника пов'язана 3 джерелами підвищеної небезпеки. Крім того, такі договори обов'язково повинні містити такі умови: а) дату початку й дату закінчення договору або його мінімальну тривалість (якщо він не містить точних дат); б) дані працівника, який потребує тимчасової заміни (забороняється укладати строковий трудовий договір з метою заміни відразу декількох працівників, навіть якщо їх відсутність є послідовною); в) його посаду й заробітну плату; г) за наявності укладеного колективного договору - посилання на такий договір. Загальна тривалість строкового 
трудового договору не може перевищувати 18 місяців, хоча існують і винятки, наприклад, коли договір виконується за кордоном, його тривалість збільшується до 24 місяців (ст. L1242-8 Трудового кодексу Франціï). 3 огляду на зміст ст. L1243-13 Кодексу розглядуваний договір може бути продовжений один раз на строк, що не перевищує максимально можливий для таких договорів. Перевищення перетворює його на договір, що укладається на невизначений строк ${ }^{10}$.

Висновки. Значний вплив на формування трудового законодавства Естонії, Італії, Польщі та Франції здійснює членство наведених країн в СС. Зазначене стосується також і Великобританії, яка досить тривалий проміжок часу знаходилась у складі зазначеного економічного та політичного об'єднання. Імплементація наведеними країнами актів ЄС у національне законодавство зумовлює існування між ними спільних рис правового регулювання строкових трудових договорів, до яких належать: чітке часове обмеження тривалості договору, закріплення максимально допустимої кількості переукладень, дотримання принципу недискримінації тощо. У свою чергу, реалізація строкових трудових правовідносин в кожній із країн відрізняється своєю самобутністю, що пов'язано з внутрішньодержавною традицією їх реалізації. Наприклад, у Великобританії звільнення працівника у зв'язку із закінченням строку трудового договору розглядається крізь призму справедливості дій роботодавця, а в Італії кількість укладених строкових трудових договорів у конкретного роботодавця не може перевищувати $30 \%$.

Наведені обставини мають бути враховані Україною при реформуванні трудового законодавства. Адже необхідність імплементації Директиви Ради 1999/70/ЄС чітко передбачена п.п. 1139 та 1140 Плану заходів 3 виконання Угоди про асоціацію між Україною, з однієї сторони, та Європейським Союзом, Свропейським співтовариством з атомної енергії і їхніми державами-членами, з іншої сторони, затвердженого постановою Кабінету Міністрів України від 25 жовтня 2017 р. № 1106.

${ }^{1}$ Emir A. Selwyn's Law of Employment. Eighteenth Edition. Oxford University Press. 2014. P. 67.

2 Collins H., Ewing K.D., McColgan A. Labour Law. Cambridge University Press. 2012. P. 177.

3 Emir A. Selwyn's Law of Employment. Eighteenth Edition. Oxford University Press. 2014. P. 406.

${ }^{4}$ Deakin S., Morris G. Labour Law. Six Edition. Oxford and Portland, Oregon. 2012. P. 202.

5 Fixed-term employment contracts. URL: https://www.gov.uk/fixed-term-contracts/renewing-or-ending-a-fixedterm-contract (дата звернення: 28.05.2020).

${ }^{6}$ Contratto a tempo determinato. URL: https://www.lavoro.gov.it/temi-e-priorita/rapporti-di-lavoro-e-relazioni-industriali/focuson/Disciplina-rapporto-lavoro/Pagine/contratto-a-tempo-determinato.aspx (дата звернення: 28.05.2020).

7 Italy: Changes to Fixed-Term Contracts. URL: https://ieglobal.vistra.com/knowledge/country-compliance-alerts/2018/8/italychanges-fixed-term-contracts (дата звернення: 28.05.2020).

${ }^{8}$ Спіцина Г.О. Особливості правового регулювання трудових відносин у республіці Польща. Науковий вісник Ужсгородського національного університету. Серія : Право. 2015. Вип. 30(1). С. 189.

${ }^{9}$ Шония Г.В. Общзая характеристика трудового права Франщии: автореф. дисс. ... канд. юрид. наук: 12.00.05. Москва, 2009. C. 26.

10 Трудове право в державах Європи: підручник / С.В. Венедіктов, Г.О. Спіцина. Київ : Ніка-Центр, 2017. С. $102-103$.

Резюме

Савчук С.П. Особливості правового регулювання строкових трудових договорів в окремих свропейських країнах.

Стаття присвячена дослідженню досвіду правового регулювання строкових трудових договорів у Великобританії, Естонії, Італії, Польщі та Франції. Зроблено висновок, що значний вплив на формування національного законодавства в сфері праці здійснює членство наведених країн в ЄС. Імплементація актів ЄС в національне законодавство зумовлює наявність спільних рис правового регулювання строкових трудових договорів у всіх членів зазначеного економічного та політичного об'єднання. Але, в будь-якому випадку, незважаючи на такі спільні риси, строкові трудові правовідносини кожної окремої країни відрізняються своєю самобутністю, зумовленою внутрішньодержавною традицією їх реалізації.

Ключові слова: строковий трудовий договір, Європейський Союз, строк дії трудового договору, підстави виникнення строкових трудових правовідносин, припинення трудових правовідносин.

\section{Резюме}

Савчук С.П. Особенности правового регулирования срочных трудовых договоров в отдельных европейских странах.

Статья посвящена исследованию зарубежного опыта правового регулирования срочных трудовых договоров в Великобритании, Эстонии, Италии, Польше и Франции. Сделан вывод, что значительное влияние на формирование национального законодательства в сфере труда оказывает членство указанных государств в Европейском Союзе. Имплементация актов Европейского Союза в национальное законодательство обусловливает наличие общих черт правового регулирования срочных трудовых договоров у всех членов указанного экономического и политического объединения. Но, в любом случае, невзирая на наличие общих черт, срочные трудовые правоотношения каждой отдельной страны отличаются своей самобытностью, обусловленной внутригосударственной традицией их реализации.

Ключевые слова: срочный трудовой договор, Европейский Союз, срок действия трудового договора, основания возникновения срочных трудовых правоотношений, прекращение трудовых правоотношений.

\section{Summary}

Sergiy Savchuk. Special aspects of legal regulation of fixed-term employment contracts of some European countries.

The article is devoted to the study of foreign experience in legal regulation of fixed-term employment contracts. Fixed-term employment contracts should be considered as one of the earliest and, accordingly, the oldest forms of non-standard employment. Turning to the concept of the application of fixed-term employment contracts in Ukraine in the near future, it seems appropriate to consider 
the possibility of their further development through the prism of studying European experience. Indeed, in many European countries the fixed-term contracts are quite common and therefore analysis of both positive and negative examples of their legal regulation will be useful for the future development of labour legislation in Ukraine.

The article features an analysis of the relevant legislation of the United Kingdom, Estonia, Italy, Poland and France. It is concluded that the membership of these states in the European Union has had a significant impact on the evolution of national labour legislation. This also applies to the United Kingdom, which had been part of this economic and political union for a long time.

The transposition of EU legislation into national law by these countries predetermines the existence of common features between them in the legal regulation of fixed-term employment contracts. This common features include: clear time limits of the employment contract, maximum allowable number of renewals enshrined in law, compliance with the principle of non-discrimination, etc.

In turn, the implementation of fixed-term employment relationships in each country differs in its uniqueness, which is due to the domestic tradition of their implementation. For example, in the United Kingdom, the dismissal of an employee due to the expiration of the employment contract is considered through the lens of fairness of the employer's actions, while in Italy the number of fixed-term employment contracts with a particular employer cannot exceed $30 \%$.

The above circumstances should be taken into account by Ukraine when reforming labour legislation. Indeed, the need to implement Council Directive 1999/70/EC is clearly provided for in clauses 1139 and 1140 of the Action Plan for the implementation of the Association Agreement between Ukraine, on the one hand, and the European Union, the European Atomic Energy Community and their member states, on the other hand, approved by Resolution of the Cabinet of Ministers of Ukraine No. 1106, of 25.10.2017.

Key words: fixed-term employment contract, European Union, duration of the employment contract, grounds for the fixed-term employment relationship, termination of employment relationship.

DOI: 10.36695/2219-5521.2.2020.55

УДК 347.72 .01

\section{Б.о. Соловйов}

Борис Олегович Соловйов, магістрант юридичного фракультету Київського національного університету імені Тараса Шевченка*

ORCID: 0000-0003-2635-4096

\section{ПОНЯТТЯ ТА ПРАВОВА ПРИРОДА КОРПОРАТИВНИХ ПРАВОВІДНОСИН: ПОЗИЦІЯ ДОКТРИНИ ТА СУДОВОЇ ПРАКТИКИ}

Постановка проблеми. На сучасному етапі розвитку має місце процес рекодифікації цивільного законодавства, що $\epsilon$ безпосереднім наслідком євроінтеграційних процесів, які активно тривають 3 моменту підписання Угоди про асоціацію між Україною та Європейським Союзом від 27 червня 2014 р. У процесі рекодифікації цивільного законодавства, окрім іншого, закономірно звернулися до проблем, пов'язаних із правовою природою окремих видів цивільних правовідносин, адже саме це $\epsilon$ необхідною передумовою для підвищення ефективності механізму цивільно-правового регулювання.

На сьогодні слід констатувати, що правова природа корпоративних правовідносин є актуальним предметом дослідження як з позиції теорії цивільного права, так і з точки зору практики правозастосування. Активний науковий інтерес до цієї сфери насамперед пов'язаний з існуванням великої кількості дискусійних питань, вирішення яких $є$ необхідним для подальшого розвитку доктрини цивільного права та підвищення рівня застосування цивільно-правових норм.

Аналіз останніх досліджень і публікацій. Проблемні питання правової природи та правового регулювання корпоративних правовідносин досліджувалися у працях Н.С. Кузнєцової, І.В. Спасибо-Фатєєвої, B.М. Кравчука, В.В. Луця, В.І. Борисової та інших вчених. Вагомими $є$ напрацювання зарубіжних дослідників, серед яких слід виокремити праці Д.В. Ломакіна та В.А. Бєлова. Водночас, незважаючи на активний науковий інтерес до питань правової природи та особливостей корпоративних відносин, низка теоретичних питань досі залишається певною мірою невирішеними.

Отже, метою цієї статті є аналіз позицій представників доктрини цивільного права та судової практики щодо визначення правової природи корпоративних правовідносин.

Виклад основного матеріалу. Вважаємо, що дослідження поняття та особливостей корпоративних правовідносин слід розпочати з аналізу положень національного законодавства.

Так, ЦК України не містить легального визначення корпоративних правовідносин та відповідних прав. Така дефініція наведена у ст. 167 ГК України, згідно із якою корпоративні права є правами особи, частка якої визначається у статутному капіталі (майні) господарської організації, що включають правомочності на участь цієї особи в управлінні господарською організацією, отримання певної частки прибутку (дивідендів) даної організації та активів у разі ліквідації останньої відповідно до закону, а також інші правомочності, передбачені законом та статутними документами. Разом із тим під корпоративними відносинами маються на увазі відносини, що виникають, змінюються та припиняються щодо корпоративних прав (ч. 3 ст. 167 ГК України) ${ }^{1}$.

(C) Б.О. Соловйов, 2020

${ }^{*}$ Borys Soloviov, Master student of the Law Faculty of Taras Shevchenko National University of Kyiv 